\title{
Managerial Reporting Tools for Social Sustainability: Insights from a Local Government Experience
}

\author{
Eleonora Cardillo and Maria Cristina Longo *(B) \\ Department of Economics and Business, University of Catania, 95129 Catania, Italy; cardillo@unict.it \\ * Correspondence: mclongo@unict.it
}

Received: 31 March 2020; Accepted: 29 April 2020; Published: 2 May 2020

\begin{abstract}
The paper is a country-specific study that explores the potential points of connection between the sustainable territorial development goals and managerial tools in the context of local authorities. In particular, the purpose of this research is to propose a set of features and criteria to evaluate the contribution of accounting documents to the pursuit, development and strengthening of social sustainability. As part of traditional accounting systems, social reporting is essential to support policy makers' decisions in promoting social sustainability and in evaluating the effects of their choices within the institution and externally towards citizens and various stakeholders. To this end, we present a leading case study of a medium-sized Italian local authority's accounting system in which the contributions and limits of managerial tools to social reporting are analyzed. The case study allows us to have a deeper understanding of social reporting and to get insights about issues that matter to social sustainability assessment in public administration. Since the reporting tools comply with international accounting standards, the case study offers interesting food for thought in the international debate on the assessment of sustainability in public organizations. The results identify the areas of complementarity and critical issues between social reporting and traditional accounting systems. Therefore, they enhance our knowledge about the role of public accounting system in supporting sustainable territorial development policies and programs through managerial tools' adoption.
\end{abstract}

Keywords: sustainability; territorial development; managerial tools; social reporting; local government

\section{Introduction}

Sustainability has long been at the heart of the United Nations Member States policies and has received great attention within the European treaties and legislations. It refers to the safeguarding of present and future generations and to the essential respect for their needs. These needs are both social and environmental, attributable to the concepts of eco-justice and eco-efficiency [1]. In particular, eco-justice is linked to the concepts of equity, especially, to the fair relations between peoples towards resources. Eco-efficiency is a concept that assumes importance not only because it refers to the careful use of scarce resources on the planet but also to the realization of a correct distribution of well-being (intra-generational equity) ensuring the growth of future generations (inter-generational equity). At international and European levels, the sustainability question is very crucial, particularly at the policy level. The Millennium Development Goal, with the international development goals (MDGs) for the year 2015, the subsequent 2016 Sustainable Development Goals (SDGs), until the 2030 Agenda for Sustainable Development, recommend developing a more flexible, cohesive and inclusive public governance that is capable of supporting the corporate social responsibility on a voluntary basis. In particular, the 2030 Agenda is a call for action by all developed and developing countries towards a global partnership, which is committed to ending poverty and other deprivations, hand-in-hand 
with improving health and education, reducing inequalities and sustaining economic growth, all while preserving the planet and tackling the issue of climate change.

In pursuing these purposes, the role and responsibilities of governments and public administrations have changed radically, due to substantial changes concerning the sustainable development goals: (1) the understanding that environmental impacts and the demand for natural resources must be limited; (2) the adoption of technological production models that require the activation of sustainable processes; (3) the awareness that sustainable development requires profound changes in organizational structures and a revision of the relationships between organizations and society [2]. Faced with a holistic approach to sustainability with respect to SDGs, the sustainable territorial development can be considered a promising area for investigating, understanding and evaluating the effectiveness of policies from an economic, social and/or environmental point of view at a local level. The sustainable territorial development refers to the territorial diversity in terms of economic, natural, social and cultural elements of a specific area (region, nation, metropolitan area, municipality, periphery). It expresses the ability to implement actions based on the identity of a territory [3-5]. Public organizations play a fundamental role in achieving sustainability. They are at the forefront of setting sustainable territorial development policy goals and have managerial tools to support their achievement [6]. The local government is a territorial public institution, since the territory represents one of its constitutive elements and its sphere of implementation of the institutional choices. In pursuing the interests of the community, the relative actions are based on a convergence between social actors and public administrators in order to guide the development of a territory.

We focus on social reporting tools in order to examine the potential points of connection between the sustainable territorial development goals and managerial tools in the context of local authorities. To favor social sustainability as a specific connotation of the sustainability, these operational tools should be combined with specific performance indicators, the composition and breadth of which depend on the ability of public administrations to "review" them according to the needs of the community towards sustainability.

Regarding the expression of managerial reporting tools, we mean the main documents of the accounting system used for the production of social information, which are integrated with the social accounting tools. Social accounting supports social sustainability and, in this sense, social sustainability accounting includes accounting tools that allow the measurement and communication of social aspects and that give a dimension of the social sustainability of the public action. Various tools can support social sustainability accounting. There is not a unique way to assess sustainability. There are several reporting activities explaining this and using several indicators to this end that are often voluntary acts summarized in the annual reports. Among the models that describe the implementation processes of social reporting systems at international and European levels are Accountability 1000, European Institute for Social Reporting and the Global Reporting Initiative (GRI), which constitute an international guide for the preparation of sustainability reports from an environmental, social and economic point of view [7]. Italian regulations regarding the accounting of local authorities (Legislative Decree n.118/2011) offer different tools for measuring social aspects in local governments, such as: a list of documents to analyze the progress of social programs and projects; social performance reporting tools; social reporting tools, including social accountability tools (e.g., social report, gender report, mandate report, sustainability report).

Among the documents described above, the social report has increasingly become the main form of social reporting and openness tools, through an exposure of responsibility to create value not only towards the internal subjects of the organization but also for the community [8,9]. For this reason, this tool has a particular connotation in the public organizations and it may be adopted to assess the sustainable territorial development, including when used jointly and in an integrated way with the traditional accounting system. 
The public body has the need to manage consent in an appropriate manner and to "give an account" to citizens: this can be done by "telling" its activity in simple language, overcoming the technical and communicative limitations that separate him from the collective sharing of his work.

The public organization pursues social ends and it is socially responsible for its institutional nature. Local authorities, for example, must give coherent answers to the needs of the community. In public managerial logic, therefore, social reporting is not only a voluntary option, but becomes an obligation towards stakeholders.

The social and environmental problems are relevant issues for sustainability and the development of social accounting is closely connected to the traditional accounting $[10,11]$. This consideration leads us to reflect on the relationship between accounting and social variables, and in particular on the form and degree of mutual influence between them. In fact, the elements that shape a social reporting system cannot be separated from the examination of the effects they have on the accounting system; however, the conditioning and limiting factors that derive from the accounting itself in implementing forms of social accounting cannot be overlooked. Being able to understand this mutual influence means investigating the real essence of social accounting as well as the meaning of accounting, as a tool that can provide the elements necessary for the detection of social aspects.

To achieve our goal, we investigate the relationship between the social sustainability and accounting system with regard to its ability to express the social aspects of public sector activity. In particular, we analyze the contribution that managerial tools can offer to sustainable territorial development, through the consideration and evaluation of the social aspects and key performances in the context of local authorities. To this end, we apply our analysis to an Italian municipality, a medium-sized local body located in eastern Sicily. This is a country-specific case study where it is possible to observe the complementarity between social reporting and traditional accounting systems. We analyze the contents and purposes of accounting documents (such as budget, DUP, PEG, financial statement, social report), required by law and their contribution to the evaluation of social aspects. This allowed us to identify the expression of social aspects and values or, on the contrary, limitations to the social communication and to the degree of sustainability. In the last decade, the accounting system of local authorities has been characterized by a process of accounting harmonization based on international accounting standards to make financial statements comparable. We believe that this case study, which concerns one of the first local authorities in Italy to use social reporting together with traditional accounting tools, offers interesting issues that may matter in the international debate on the assessment of sustainability in the public organizations.

The findings add knowledge to the literature on sustainability, highlighting both the contributions and limits of the managerial tools in public administration and the institution's ability to reach what has been defined in the planning phase. They can also provide guidance for policy makers, administration staff and practitioners to implement social reporting systems, which are well integrated with the traditional accounting system. The results give insights for management to represent and assess the economic, financial and equity results in terms of the social dimension. Finally, the information derived from this integration allows the generality of the subjects (local municipality, citizens and the other stakeholders) to express judgments on the management's capacity to effectively achieve the objectives that were previously established.

The study considers the literature that address the sustainability of a territory (Section 2) and the integration of social accounting with the traditional accounting system (Section 3). It intends to contribute some new insights into the sustainability literature. The case of an Italian municipality is also presented (Sections 4 and 5) in order to verify, through an interpretative approach, the way in which the accounting documents are interpreted with respect to social purposes and if they specifically manage to satisfy the related information needs. The results (Section 6), contribution, implication and open questions (Sections 7 and 8) show that there is often a complex relationship between the accounting system and social reporting. As evidenced by several authors [12-17], sometimes it is difficult to associate social reporting systems with traditional accounting, highlighting a conflict of 
goals. Starting from the consideration that the purpose of any social or environmental accounting should be the improvement of the overall conditions of the world and of the degree of responsibility of organization actions towards the community, it is necessary to ask whether the structure and innovative processes of the accounting systems can favor this process [18] and if, in particular, the development of social accounting can be linked to the consolidation and purposes of traditional accounting.

\section{Exploring Sustainability in the Context of Local Authority}

Sustainable development is traditionally linked to the economic, environmental and social dimensions. Its main objectives are the balanced economic growth, full employment, social progress and an adequate level of protection and improvement of the quality of the environment. Sustainable development has long been a very crucial issue at the heart of the European Union policies and legislation, starting with the Millennium Development Goal, which established the 2015 international development goals (MDGs), the subsequent 2016 Sustainable Development Goals (SDGs), up to the current 2013 Agenda for Sustainable Development, which defines the project for global sustainable development $[19,20]$. 2030 AGENDA sets 17 sustainable development goal; among these, goal 17, regarding the "Partnership for the Goals", aims to strengthen the means of implementation and to revitalize the partnership for sustainable development. The data monitoring and accountability area requires that the national statistical laws of the countries comply with international principles, including scientific methods, professional ethics, standard procedures for monitoring data and accountability. These objectives are global and provides a shared blueprint, applicable on the basis of the country characteristics, where the three dimensions of sustainable economic, social and environmental development are integrated.

Sachs [21] extends this concept to the interaction of four systems: the world economy, the Earth planet, the global society and the good governance. The joint consideration of these four dimensions outlines the concept of sustainable territorial development. According to Medeiros [3,22], the main policy dimensions associated with the concept of sustainable territorial development are: circular economy to maintain the value of resources as long as possible by returning them to the product cycle at the end of their use; social environmental awareness to educate an environmentally proactive society; environmental conservation for a sustainable exploit of the natural resources, terrestrial ecosystems' protection and restoration, global governance sustainability focus to share the knowledge, capacities and technologies to foster global sustainable development actions, global spatial planning sustainability focus to manage the planet and its elements (river basins, seas, mountain ranges, ice caps, forests) with a sustainable development approach.

The development of the 2030 agenda has led to the growth of interest in social accounting. The debate around the environment issues leads to two social reasons: the social reasons for which the environment continues to be degraded and the social impact that derives from this situation. For these reasons, it is difficult to make a clear distinction between the environment and social problems. In essence, the debate on the environment inexorably leads to issues of sustainability and these issues, by definition, embrace the issues of social accounting [18].

However, faced with a holistic approach to sustainability with respect to SDGs, sustainable territorial development can be considered as a promising area for investigating, understanding and evaluating the effectiveness of policies from an economic, social and/or environmental point of view at the local level [23-25]. Sustainable territorial development expresses the ability to implement public policies based on the identity of a territory. As noted by Medeiros [3] (p. 3),

"In essence, what distinguishes sustainable development and territorial development is the notion of sustainability (a goal or condition vis-à-vis the process of sustainable development-[...] which needs to be associated with the notion that future generations have the right to enjoy a clean, socially and economically prosperous, and well-governed and planned world." 
The relative actions are based on a convergence between social actors and public administrators in order to guide the development of a given territory [5]. The territory, in this sense, is understood not only in a physical sense but as the set of social relationships that are created and guide the development of a community, with its economic, social and cultural connotations. Public institutions need to move, taking into account the identity of the territory and creating conditions for promoting development in its multidimensionality.

The key to achieving the sustainable development of a territory is an understanding and modeling of its identity, given by the interactions between the natural system and the socio-economic ones, its cultural capital $[4,26,27]$. The nature of this relationship is constantly evolving, just as species are born and become extinct and resources end, and others are rediscovered, so socio-economic systems expand and shrink. Sustainable territorial development can refer to different levels, and in particular to regional and local or relative to a country, a continent or the entire world economy.

We delimit our analysis at the municipality level, focusing on the local authority as a decision-making actor capable of representing, communicating and expressing the territorial development of an area both in terms of economic value, but also in terms of social and environmental capital. The local authority is defined as a territorial public entity because the territory represents one of the constitutive elements and the sphere of implementation of the institutional choices. To promote the economic development of the administered community, it is necessary to consider the resources available. The local authority tries to maximize the value of the territory, so that the local community can achieve its development, respecting its sustainability. In this sense, it is essential to identify the actions that the local authority puts in place to achieve the effective development of the territory. Among the operational tools to achieve these objectives, there is the accounting system. The budget or a social report of local authority offers not only a technical representation but is the heart of the activities and opportunities of a territory. The creation of social accounting systems integrated with traditional accounting develop a continuous communication process aimed at involving the multiplicity of institutional, social, economic and cultural local actors of the reference territory.

This approach, which incorporates economic, social and environmental aspects of a territory, it can consider partially expressive of the concept of sustainability. First of all, in the confluence of these elements, one aspect cannot be given priority over another; moreover, it cannot be said with certainty that they represent and describe all the changing dimensions of sustainability. Indeed, it is believed that these dimensions do not exhaust the field of sustainability, which is in constant movement [2]. Besides this, the social dimension of sustainability has received less attention than the other components due to the difficulties in realizing and operationalizing it [3]. Starting from these considerations, sustainability and accountability are closely connected.

The concept of accountability refers to the duty to account for the actions for which you are responsible. It pertains to both social, economic and environmental aspects. It is believed to be related to the concept of sustainability [28], whereas social sustainability is closely linked to social problems and even constitutes a social value itself $[2,29]$.

The consideration of the social relevance of these phenomena means that they can be traced back to studies relating to social accounting.

The idea of "social" arises from the consideration that society and the economy influence the environment in which they operate. Therefore, in the economic system of all organizations, the state and stakeholders play an important role in the process of the economic and social improvement of the territory. These considerations underline the importance of the political-institutional role of public administrations in attributing importance to social aspects and expansion of the traditional and restricted communication channels that regulate relations between public bodies and the social context. In this sense, social accounting, as relevant tool for social sustainability, represents an evolutionary and improvement mechanism of the current structure of organization, through consideration of the social, ethical and environmental aspects following the principle of transparency and visibility and therefore of accountability. This tool allows the development of democracy and therefore increases the 
contribution of the people. The development of a social accounting model activates the process of re-democratization of society in this sense [30], starting from the local territory.

Social accounting becomes essential to provide adequate information to stakeholders, both socially and environmentally [1]. In particular, sustainability accounting is used to create a survey system that analyzes the financial implications of sustainability with respect to the different social, environmental and economic dimensions for organizations and individuals [2].

\section{Addressing Social Accounting and Traditional Accounting Relationship: A Literature Review}

Public administrations are called upon to evaluate multiple economic, social and political aspects that significantly influence management methods and production processes, making decision-making complex. These characteristics make it more difficult to create and feed the conditions for activating public accountability processes.

The creation of mechanisms based on accountability therefore implies the activation of a reporting system which must report the results and effects of the organization activity towards all stakeholders in various dimensions, not only economic and financial, but also social, civil and environmental [31-35]. The information produced considers several aspects related to the sustainable territorial development policies: the quality of the results, timing of their realization, resources' distribution on the territory, public order, cultural and social effects, and quality of community life.

Accountability has historically been addressed in different ways, and the prevailing idea of public accountability has changed over time in relation to the social, cultural and political-institutional contexts that have extended its significance and prospects for investigation [13,31,36,37]. The accountability principle has different dimensions [16,38-41] and the development of accountability channels in the public sector can be linked to institutional processes and the renewal of information and evaluation tools $[32,40,42-45]$.

The ability of public organizations to create social value over time depends on the degree to which it shares ethical-social principles with its interlocutors. In the public sector and in non-profit organizations in general, profit has little relevance. Basically, there are no profits or economic calculations guiding their decisions. In other words, strategic choices are not adopted according to a purely economic criterion. Profit is not configured as an indicator of economic-financial feasibility and therefore does not constitute a target for organizations operating in the public sector. These realities perform a service towards society, and to fulfill this task they manage the resources of the community. The concept of accumulation is in contrast with the nature of these bodies, as their ability to offer services efficiently and effectively is the basis of their work.

The fact that profit is not a suitable indicator for these entities leads to the need to identify appropriate performance indicators that give a measure of the quality of their choices [5]. These indicators consider the relationship between the definition of these performance indicators, essentially based on the measurement of efficiency, effectiveness and economic stability, and the development of a social accounting system. These tools should be integrated with social sustainability accounting, through which the environmental and social aspects of the organization are monitored, measured and communicated to the various interlocutors. The measurement of public action provides important information for the community, useful for monitoring, comparing, and improving critical aspects of the performance achieved by providing useful evidence that allows managers to better define objectives, improve particular activities and the level of services, and investigate particular negative or unusually positive trends [46].

The institutional purpose of the public sector seeks to direct public spending towards the sustainable growth and enhancement of public services. The consideration that financial resources that come from the local community forces the public body to maintain and guarantee a complex and precarious balance aimed at achieving a qualitative increase in the level of services, without this leading to an increase in the level of taxation. In this dimension, the social accounting system becomes essential, because it offers the community an appropriate way of interpreting institutional choices. 
The international literature offers interesting conceptual and critical aspects of social accounting, related to the deepening and substantial delimitation of different meanings related to the evolution of this discipline [11,47,48]. Specifically, Gray et al. [48] address the social accounting community by critically highlighting the importance and the need for the public and the third sectors to take care of social accounting development.

The study of the relationships between accounting and social implications has always intrigued researchers. In 1971, Goldberg [49] identified the relationship between accounting and the social context, stating that economists and statisticians began to develop the social implications of accounting techniques and the economic influences of its procedures and concepts.

The contributions of Prakash [50], Fitch [51], Bowman and Haire [52] have focused on analyzing the relationship between social responsibility and the benefits for society in terms of the positive results it achieves. Belkaoui [53] carried out an experimental study to determine the impact of socio-economic declarations on investment decisions, affirming the relevance of this information for making strategic investment decisions.

On the basis of social accounting, the literature has developed the notion of a social contract, according to which each institution operates in society through an implicit or explicit social contract, whose growth and survival are ensured by the implementation of the actions expected and requested by the organization and the distribution of economic, social and political benefits to those from whom each organization derives its power [54]. Shocker and Sethi [54] studied the stakeholder perspective in managerial choices. Their research shows that managers use a multidimensional criterion to fulfill social responsibility, which includes the stakeholders' perception. According to these authors, social legitimacy is fundamental for the organization's survival.

Some authors $[55,56]$ have linked the social contract to the logic of organizational legitimacy: organizations try to establish a congruence between the associated or implicit values of their activity and the set of rules of the behavior of the social system they are part of. The conceptual models of social responsibility accounting have always been developed in order to define the areas of responsibility and the communication divergences of organizations [57-62]. Ramanathan [57] underlined the connection between the measurement of social aspects and accounting and highlighted the importance of generating accounting data on social aspects to understand how the economic benefits are distributed among the various groups of subjects. Gray et al. [62] discussed the relevance of corporate social responsibility in accounting in order to measure the actions for which an organization is socially responsible.

The issue of social information disclosure is analyzed by Lindblom [60]. He investigates the relationship between social performance and social disclosure, trying to define their possible mutual interaction. The author, through the analysis of 160 social reports of different companies, confirmed the existence of a mutual influence between different areas of social responsibility and the ability to communicate social performance. Some authors [63] investigated the phenomenon of voluntary reporting by Italian local authorities, exploring the financial and non-financial reporting models and the factors that influence these tools. Empirical analysis revealed a diversified situation. In the context of a management reform process, various factors, such as the type of activities carried out and the strategic priorities of the authorities, significantly influence the content of the social reports.

Social accounting can be defined in general terms, and also in consideration of its extension to the public sector, as a communication process on the social and environmental effects of an organization's economic actions towards particular interest groups present in society [30]. This definition clarifies that the existence of a social accounting system involves a communication process between organizations and its stakeholders based on a concept of accountability that goes beyond the traditional role assumed by traditional accounting [5]. This goes back to the sphere of sustainability accounting as a tool to improve the social context and the living conditions of the local community.

Accounting performs two essential functions within an organization: registration and collection on the one hand, and the collection and dissemination of information on the other. In this sense, accounting is defined by Belkaoui [64] (p. 22) as "the process of identifying, measuring and communicating 
economic information to permit informed judgments and decisions by users of the information" and with respect to its function [65] (p. 38), it is "a service activity. Its function is to provide quantitative information primarily financial in nature about economic entities that is intended to be useful in making economic decisions, in making resolved choices among alternative courses of action". Pallot [17] affirmed that accounting is considered not only as a system of representation and classification but also a language that influences the way of perceiving the world. In the communicative value of accounting, it is understood how, through the representative and communicative moment of management results, the entity transfers not only accounting data but also its value system.

The concept of social responsibility can therefore refer to the voluntary dissemination of information (quantitative and qualitative) produced by an organization to inform or influence a part of the community. Part of the quantitative information may be financial and non-financial, but in any case, data and assessments of potential interest for employees, the community, owners and creditors are included.

Traditional accounting systems in their broadest sense include some essential, although not exhaustive, characteristics [30]: the financial description; the evaluation of economic events; the definition of organizations and accounting data; information for specific users.

Gray et al. [30] stated that social accounting is a combination of accounting for different areas (as well as for economic events); accounting in different ways (as well as in financial terms); accounting for different individuals or groups; accounting for different purposes. In these terms, traditional accounting could be understood as a particular form of the wider area of social accounting, which is therefore configured and implemented when the artificial restrictions of conventional accounting are removed. In essence, social accounting, which traditionally is considered a part of economic and financial accounting, is understood by the author as a possible "universe of accounting practices" which includes, according to an extreme vision, traditional accounting.

Beyond this delimitation, which cannot be circumscribed and defined in an absolute way, it can be said that the current drive to innovate public accounting systems is aimed at pursuing a growing need for accountability that influences the structure of the accounting information system [66-68].

The introduction of tools to evaluate social variables in the structuring of the accounting system highlights, in the most recent scientific approaches [63,69], the value assumed by the methods of transmitting information; accounting is in fact conceived not only as an activity of mere measurement and selection of data but also as an important tool for information transfer and communication of social values and the two functions are closely connected and correlated [70,71]. Specifically, Crane [71] underlined the relevance of communication processes by creating a conceptual framework of the different theoretical approaches concerning CSR communication.

The social accounting therefore identifies a terminological meeting between accounting and social; if the identification of the economic-financial aspects and the concepts of management and taxation help to explain the concept of accounting, the same does not apply to the "social", whose defining elements take on a wider dimension and cannot be easily framed in a univocal way.

In this paper, we believe that social reporting tools should be integrated with traditional accounting tools and have the same importance. In order to better understand how managerial tools contribute to sustaining sustainable territorial development policies and programs, we apply our analysis to the context of a local authority in Italy. This country has been characterized by a reform process of the public administrations directed to the pursuit and strengthening of social sustainability. To this end, we present a leading case study of a medium-sized Italian local authority's accounting system in which the contributions and limits of managerial tools to social reporting are analyzed. The country-specific study, analyzed below, allows us to have a deeper understanding of the social sustainability of a territory in terms of the economic efficiency, social inclusion and environmental responsibility of a local community. It can be useful in identifying interesting elements for integration or critical issues related to the collection and reliability of data, and to get insights about issues that matter in the social sustainability assessment in public administration. 


\section{The Evolution of the Italian Local Authorities Accounting Systems}

The growing awareness of the social reporting potential is linked to the renewal process that has characterized the reform of the public administration in the last two decades [72]. The reform process was characterized by the attempt to redevelop the public administrations activities through a redesign of their organizational structures and of their accounting system. These activities are more linked to generating results according to the criteria of transparency and economic efficiency [73].

The path of accounting systems renewal represents the continuous effort by public institutions to achieve a coherent relationship between the decision-making processes and the purposes that a local body pursues. In particular, in order to overcome the self-referencing logic of local authorities, it is necessary to more specifically identify the issues to which the administration's work is directed and to more concretely define managerial responsibilities and benchmarking processes. It is necessary to activate the rules and principles that lead local administrations to attribute a social value to their choices; these choices involve multiple aspects that have significant economic and social effects in the territory. They concern the allocation of financial resources, investment policies, changes in organization assets, technical-organizational models, service delivery methods, territorial promotion and local development.

The growth of the social value indicates a greater attention to external communication processes, through which public organizations communicate the results of their management according to mechanisms of accountability and transparency $[5,73]$. The development of this process makes it necessary to rethink and renew the detection and reporting systems, which must be adequately designed and structured according to specific territorial needs. The revision of public administration accounting systems has been very marked in recent years. The traditional planning and reporting phases have expanded their contents and the information flow (Legislative Decree n.118). Examples of the accounting system renewal are the Single Programming Document (DUP), the introduction of the accrual accounting for information purposes, the evaluation criteria definition of the items of the income statement and the financial statement, the introduction of new forms of control and the extension of the content of the Executive Management Plan content (PEG). The accounting principle in programming ensures that, in the strategic planning documents, local authorities produce the tools through which the local authority intends to report and communicate the activities carried out and the degree of achievement of the objectives according to specific areas of responsibility. More specifically, the Single Programming Document (DUP) constitutes the body's strategic and operational guide. It includes the contents of documents that were previously attached to the budget, such as the Programming Report, the Programming of Public Works, staffing needs, disposals and enhancements of assets. The DUP therefore enlarges the information previously contained in the programming report and also its structure, which includes the strategic and operational section, allows a more coherent connection with the operational programming of the PEG.

In order to achieve an integration between the two systems, it is necessary to create a link between accounting data and social information. In this sense, the accounting system also becomes instrumental to the social reporting needs, whose cognitive function is to respond to the stakeholders' expectations, trying to promote sustainable development of the territory. The accountability logic is ensured by the structuring of accounting systems designed to guarantee qualitative and quantitative information through an appropriate reclassification and remodulation of the items, according to external communication purposes which are conveyed by social accounting tools.

The structuring of an accrual accounting system, if it is validly and usefully integrated with the cash accounting system, constitutes a particularly effective tool in the process of measuring the overall results of the local authority, with reference to the evaluation of the social performances achieved. The literature on this subject does not converge in attributing to the accrual accounting a decisive role for public administrations' management. In fact multiple experiences provide some examples of implementation poorly effective in determining reliable results due to the inadequate implementation process of the tool [74]. In this sense, data on the costs and revenues that derive from 
accrual accounting are particularly useful for measuring performance economic, and the assessment of changes in an organization's assets is a highly significant and expressive index of the institution's ability to guarantee and preserve its tangible and intangible assets over time, also for the benefit of future generations $[75,76]$. The cash accounting system, which established the managerial culture of public administrations, is essentially based on a process of allocating financial resources according to an economic rationality criterion that guides the assumption of the political-managerial choices. For the main aspects, this system is suitable for the nature and purposes of the local authority, which are characterized by the accounting management of the traditional income and expenditure phases [77-79]. The results of the accrual accounting would constitute an enrichment of the cash accounting system by analyzing the essence of the phenomena in their temporal economic interdependencies. The information on costs and revenues allows to determine, according to a criterion of economic competence that joins the juridical-financial criterion proper of the cash accounting, the data on the costs of the services provided generating useful information for decisional purposes.

In this sense, the systematic reporting of the dynamics of the costs of services can identify the expense centers in detail, and therefore help to implement more effective control processes. This information is therefore essential for achieving greater efficiency of the services provided by the local authority in order to make them more suitable for the needs of the community, thereby improving their social impact.

In this sense, the structure of accounting systems influences the quality of the social reporting systems' development. If, therefore, internal and external social communication assumes a high value in management processes, it is appropriate that it also improves the quality of the accounting systems for producing and selecting information, which thus become a valid instrument for collecting data and reliable values.

\section{Research Design}

In order to identify promising managerial tools to support sustainable territorial development policies, we investigate social accounting systems. They are specific and relevant tools for promoting social sustainability. Given the exploratory nature of the paper, we analyze the accounting system of a medium-sized Italian municipality through an explanatory case study [80-82]. This approach is suitable for acquiring the perceptions of subjects operating in the field with respect to the contribution that the accounting system generates for social reporting. This is not intended to define an empirical basis for subsequent generalizations [83] or detect causal effects [84] but to understand the specificities of a real context to evaluate the issues that emerged in the theoretical framework. We note that this case study offers interesting issues that may matter to the international debate on the assessment of sustainability in the public organizations. As is known, the accounting system of local authorities has been characterized by a progressive accounting harmonization based on international accounting standards to make the financial statements of different organizations around the world comparable. Therefore, even if each local authority has a specific context, the results of our analysis can also be useful for the other local authorities involved in the same standardized system. Specifically, this case study allows us to identify areas of complementarity between social reporting and traditional accounting systems. It also raises critical issues related to differences in reporting and data reliability, which may be of interest to other public organizations located in other countries.

The choice of the Municipality, as a research site, is due firstly to the availability of both documentary and interview data and the adoption of the social report since 2015 as a communication tool to the community. In fact, the local authority selected was among the first in Italy to use social reporting together with traditional accounting tools. Secondly, this local authority adopted the tools of social accounting before the provisions of the law and has long given great attention to the issues of social sustainability. Besides, this is a leading case study where it is possible to observe the complementarity between social reporting and traditional accounting systems. Finally, this single case is particularly interesting since it allows us to understand issues related to social accounting systems 
for social sustainability in the particular context of public administrations. The results are useful for policy makers to define managerial tools that can better integrate the two accounting systems in support of sustainable territorial development policies and programs. We adopted the protocol for case study analysis, traditionally used in the literature [84] both in the selection of the unit of analysis and in data collection through archival documents, social reports, and interviews with key informants.

The research was carried out from February 2018 to November 2019. However, the study took into consideration the period from 2011 onwards, as in that year there was an important regulatory innovation that changed the accounting system of local authorities. A retrospective approach was therefore adopted, through which we tried to represent, through the perception of the interviewees, the ways in which the new regulations in question can contribute to the development of social reporting systems.

The data were collected through interviews, direct observation and document analysis. The interviews involved politicians and administrative staff, such as the Mayor, the Deputy Mayor and seven members of the Board; the municipal secretary, the manager of the Financial and Asset Service, the Head of the General Affairs, Social, School and Cultural Services, the Head of Sports and Tourism Promotion Sector, nine Councilors. The total number of respondents is 22 . We preferred to interview the local government's internal stakeholders, since they are the actors entitled to use the managerial tools for sustainability. The adoption and integration of the social accounting system is a managerial choice that involves politicians and administrative staff at the forefront. Other local government stakeholders, although they are part of the community, are mainly services users and are, therefore, not directly involved in local government decision-making on sustainability issues. Instead, external stakeholders are relevant to assessing the other side of social sustainability in terms of communication effectiveness and perception of the accounting documents. The interviews were conducted individually in the form of informal and focused semi-structure interviews, during which we flexibly collected the spontaneous opinions of the respondents on common topics. Each interview lasted $30 \mathrm{~min}$. The transcripts of the interviews were made known to the respondents who approved them. The interview scheme is based on the following issues:

Section 1-Institutional and organizational preconditions:

- System of values and principles assigned to social reporting;

- Strengths and weaknesses of the administrative structure;

- Accounting information system's deficiencies that limit the adoption of social reporting tools;

- Political-institutional relevance of the social reporting tools for sustainable territorial development decisions.

Section 2-Accounting instruments features for social sustainability:

- Quality of communication;

- Transparency;

- Stakeholders mapping;

- Consistency and reliability of the social accounting systems;

- Integrated accounting and procedures;

- Social indicators' identification and selection;

- Application context of the social indexes;

- Incentive and evaluation systems.

The direct observation concerns the participation in some meetings of the Executive and in the Services Conference. The documentary analysis concerned the following documents: the Single Programming Document (DUP), the three-year financial statements, the Executive Management Plan (PEG), and the Statement and the Social Report of the last three years. 
From the interviews, we tried to perceive and therefore identify those elements through which traditional accounting can influence social accounting practices.

The municipality analyzed renewed its accounting system. In addition to the purpose assigned to the usual programming and reporting processes, efforts have been made to increase the content of the information produced to strengthen the role that the local authority assumes in the growth of and improvement in the local community's conditions of life. In fact, each subject has a reasonable right to know the results of the local authority activities; the production and usability of information must satisfy these information needs through adequate reporting tools.

On the one hand, the accounting system must be able to provide information on financial data, methods of managing income and expenditure phases, economic components of the services performed, management evaluation systems and modifications relating to changes in the assets. On the other hand, it must allow, through communication tools, to assign a different configuration to this information in order to disseminate, using a simple language, data and values to the interested parties on the activity of the municipality and on the quality level of the services performed.

The programming and management processes are oriented towards these purposes by ensuring the system towards social as well as economic-financial objectives, through the sustainable management of available resources and an effective system for measuring and monitoring performance.

To understand these aspects, it is necessary to interpret the contribution of the information-accounting and communication tools and the ways in which the different documents can produce social information to evaluate the qualitative and quantitative level of services rendered to the community and the effective allocation of the financial resources.

\section{Findings}

In our case study, the local authority stimulates the development of social reporting systems or direct participation tools for citizens that allow a social assessment of the administration's activity in terms of the effectiveness and efficiency of the services provided.

The mandatory information content of the budget system is the basic tool for the evaluation of the interventions adopted and the effects of the political-managerial choices undertaken. The revision of the accounting system for social purposes first of all involves the expansion of the information content to meet the usability and accessibility requirements relating to voluntary external communication. Furthermore, it entails a reinterpretation of the accounting documents in order to structure the reporting systems of the social variables.

The accounting system therefore becomes essential to support the management system in this renewal process and constitutes the institutional basis for assessing the transparency, social and environmental sustainability of public choices [17]. If there are two accountability profiles, the external one and the internal one, it is necessary to establish how the accounting system must be structured in order to guarantee the maintenance and respect of these profiles $[6,36,38,40,43]$.

To this end, through a reconnaissance of the main documents that make up the local authority's budget system, we identify their information and the purposes underlying them, their interdependencies with respect to the different management periods and the values attributed by the respondents according to the cognitive needs of social reporting.

\subsection{The Mandate and Programming Documents: Contributions and Limits}

The programming activity plays a particularly central role in the local authority accounting system, whose basic logic is given by the so-called authorization function of public accounting, through which the spending limits, which the institution will have to respect in the subsequent period, are set in advance.

The strategic and political importance of the preventive phase lies in the political and management decisions formalization indicated in the plans and programs, and whose aim is to acquire prior consent on the use of resources. 
The planning phase that takes concrete form in the preparation of the preventive documents represents the "contract" that the local authority signs with the citizens and the various stakeholders as the convenience judgment on the destination of the financial resources becomes a prerequisite to regulate relations between the administration, their citizens and political consensus acquisition.

In this perspective, the reliability and consistency of the contents expressed in the preventive accounting documents become an indication of the entity's reliability and credibility; compliance with the commitments undertaken and the evaluation of the activities will then be evident in the statement in which the final management results are expressed.

The planning phase includes the Mandate, which has a particular value in identifying the programmatic lines aimed at explaining the actions to be activated for the economic and social growth of the territory. However, almost all of the interviewees believe that the document is often not developed effectively and exhaustively. The mandate programming includes the mandate program lines and the single programming document.

The Mandate programmatic lines constitute the first document through which the Mayor defines, before the mandate period, the specific program of political and managerial activity that he will carry out and, for this purpose, constitutes an essential document through which citizens they can evaluate intentions and objectives in advance.

In accordance with the budget, the Single Programming Document (DUP) expresses the lines of actions and the functioning of the offices, the services to be ensured, the current financial resources that can be acquired, the investments and the public services to be carried out, expressing the compatibility of these actions with the financial constraints.

With regard to these documents, the respondents believe that they constitute an important basis of analysis for the definition of the local authority social mission, which is fundamental in the social reporting system structuring. The interviewees, for $80 \%$ of public managers of the institution, affirm that the limited content or excessive generality of these documents does not allow to both define the mission and to reliably frame the political project proposed by the administration.

The recognition of cultural, institutional and social values highlights the characteristics assumed as guidelines which characterize the entity's way of operating; this includes the purposes that guide their strategies and methods for implementing the objectives [63]. The clear and concrete expression of the administration's political project becomes an essential point for the final evaluation of the activity in order to verify the effective achievement of the previously expressed objectives.

The single programming document (DUP), drawn up by the executive body and approved by the Board, is deemed necessary to define the strategic lines contained in the social mission.

Its structure is specifically regulated by the law, which establishes its models and contents in detail. The document describes the general characteristics of the population and territory, the economy and the organization of the institution's services and human, instrumental and technological resources. It constitutes relevant support for the political administrators and public managers as it highlights the overall dynamic of resources and strategic and operational objectives with respect to the reference period.

The particular value assumed by the document lies in the completeness of the information obtained from the description of the following statements:

- Survey of the general characteristics: it includes information relating to the population, the territory, the economy, services and organizational structures;

- Definition of the objectives through which the service managers formulate proposals relating to their lines of activity;

- Assessment of resources: the financial resources are analyzed in order to assess the relative sources of financing, highlighting any constraints with respect to the set objectives; resources are also analyzed with respect to the percentage deviation from the values of previous years;

- Programs and projects identification and drafting: the programs to be implemented are selected on the basis of the financial resources identified. 
Based on the perceptions of sixteen interviewees (about 75\%), the relevance of the document for the purposes of social reporting is due to its support in the implementation of the intervention lines, since it expresses the socio-economic purposes to be achieved through public action. The information allows a reading by problem areas, by intervention and for activities aimed at specific purposes, offering the possibility of providing a document that aligns programming activity, use of resources and management results.

These aspects are in fact fundamental for the preparation of the so-called Mandate balance sheet, which constitutes a reporting tool aimed at transparently demonstrating the actions carried out during the mandate in relation to the policy lines described by the political body. In particular, the current legislation (in accordance with the accounting principle of the Legislative Decree No. 118/2011) requires that the local authority indicates the tools it will adopt to communicate the results to the community in advance. For this purpose, performance measurement tools, reporting programs and projects, and also social reporting tools, including the social report and mandate balance sheet, can be adopted. In this sense, the Mayor comments on the last regulatory provisions, as follows:

"Our administration has drawn up the social report for several years, therefore the recent regulation has consolidated a path already started... we must focus, above all, on quality and quantity of the data that must be further developed to improve the content of the social report".

The political part has highlighted that these tools allow to identify: the areas of the entity's action with reference to the services offered and the interventions carried out; the economic, financial and equity situation at the beginning and end of the mandate, by analyzing the choices made in consideration of financial constraints; the consistency of the policies adopted with respect to the previous administration's choices.

The three-year forecast budget also has considerable relevance as it shows the programming capacity of local authorities from a medium-term perspective, allowing administrators to effectively perform their role as a guide. Although all respondents point out that the late approval of the document often does not allow for adequate planning and the timely formulation of objectives. With reference to its relevance for social purposes, it is interpreted as a document which provides a clear and complete vision of the actions to be taken in relation to the objectives and results corresponding to the purposes expressed in the local entity mission. Some interviewees say that this relevant planning document is often considered as a mere mandatory fulfillment, neglecting the importance and the essential role it plays in planning and management results. The forecast budget represents the information document not only for the subjects operating within the local authority but also for the citizens interested in knowing how the political choices have become budget forecasts, relating to the allocation of available financial resources. For these reasons, the underlying objectives have a purpose and a public interest since their configuration will determine the related economic and social impacts on the territory.

Several technical managers underline the double value of the document: the internal value due to the importance of knowing the forecasts formulated for the administrative activity and for the services responsible management, and the external value due to the interest of stakeholders in specific information on the financial resources destination.

Fifteen respondents (about 70\%) say that through social reporting systems it is necessary to make financial information usable and accessible, overcoming the technical accounting that characterizes the drafting methods of the forecast document. In this case it is necessary to create a system aimed at reclassifying, according to specific criteria and instrumental logics, the data expressed in the programming document, in order to make them readable through the adoption of a simple and immediate language [17]. The remaining portion of the interviewees consider the reclassification process not always useful since they believe that the effort produced to develop a document that can be used by the community often does not correspond to the benefit for the management of the entity. On the purposes of the budget for social purposes, the Deputy Mayor says that: 
"Defining a reclassified budget for social purposes requires a complex work of selecting data for groups of stakeholders... to date, in fact, the municipality has defined only the social report which presents the main final results and some preventive values to evaluate the deviations.... We do not exclude that in the future the administration may think about creating the budget for social purposes".

Almost all of the respondents consider the Executive Management Plan (PEG) an important document for management planning. On the one hand, a resources rational allocation is carried out in relation to a process of identifying responsibilities and defining the management objectives; on the other, a structured negotiation process is started, during which the political bodies coordinate with the technical bodies to define the operational objectives and choose the best combination of available resources and achievement of the objectives. For these essential aspects, in order to ensure the consistency of the contents, the PEG is linked to the employment plans' development and to the project activities highlighted in the Single Programming Document (DUP).

The interviewees highlight the relevance of the PEG as a tool that favors the growth of accountability. It expresses the degree of involvement and sharing of managers, which is essential for the proper functioning of public services. Through its technical-managerial function, it is an indispensable support role for management control. In this sense, the social nature derives from the consideration that the interaction mechanisms with the stakeholders activated by the social reporting processes are connected to management control activities, of which the PEG is an essential part.

\subsection{Social Sustainability Reporting in Public Administration}

The statement preparation constitutes the moment of verification of the management results through the representation of the economic, financial and equity results. The outcomes, highlighted in the final document, show the institution's ability to reach what has been defined in the planning phase. Therefore, stakeholders can express a judgment on the management's capacity to effectively achieve the previously established objectives.

For sixteen interviewees, these main purposes consist of disclosing the economic and financial situation to the local entity's administrators and in evaluating the congruence between the management processes carried out and the lines expressed during the programming activity.

The data provided through the final document are representative of the phenomena and represent a useful management tool if their representation respects the logic and rules for the correct accounting and temporal representation of the management phenomena.

The perceptions of the integrated accounting system are conflicting. The service managers affirm that the data and information of accrual accounting can perform a profitable informative function if they derive from a well-established economic and managerial culture and if they are correlated, in a coherent way, to the report expressed in terms of cash accounting [74-76]. The political part does not attribute a fundamental role to integrated accounting, stating that the accrual accounting measurement for the local authority is negligible. The Financial and Asset Service Manager highlights the usefulness of an integrated system by stating that:

"Integrating accrual accounting with the cash accounting system can be useful for determining measurement values of economic efficiency and understanding the dynamics of management costs ... furthermore these data can be essential for the determination of certain economic indicators".

Twenty respondents (about $90 \%$ of the interviewees) say that, for social reporting purposes, the explanatory note of the executive body plays a fundamental role, in which both judgments on the efficiency and effectiveness of management and a detailed description of criteria adopted for drafting of the various final documents are expressed. Furthermore, almost all of the respondents affirm that, by reading the data and information highlighted in the report, there is concrete evidence of the accounting and qualitative results of the overall management of the institution not only towards the subjects internal to the local administration but also towards the community interested in knowing 
these aspects, in order to be able to express an opinion on the economic-financial dynamics relating to the management and use of resources.

The social reporting systems express an assessment of the objectives achieved with reference to the overall work of the administration and, in this sense, the institutional final documents should provide that information which, suitably adapted and reclassified, highlights those essential elements for carrying out this assessment.

The local authority has been drawing up the social report for seven years, which is considered by the administrators to be a report of the municipality incomes and expenses in a simple and usable communicative language. The intention of the local body is to build a communication channel to improve administrative transparency and support the principles underlying participatory democracy [73]. Information makes citizens aware of and involved in public action. The accounting data are presented in the form of numbers and descriptive graphs so that citizens can understand the administrative choices and judge the economic situation. As the Mayor of the local authority expressed, it is necessary to provide specific institutional procedures for the reports approval and to define forms of citizens' participation in political choices.

The analysis of the social report shows some critical points. First of all, the report presents a structure that does not define the distribution of resources by stakeholders. The articulation is done by management areas and not by categories of subjects. In addition, the data are mainly derived from cash accounting; in fact, cost items are presented only for some services. In addition, there is no analysis of the evaluation assets and the measurement of qualitative management indicators.

The social reporting systems as a tool for spreading accountability are recognized by the interviewees [30,57], even if there is a lack both in the information production based on accrual accounting data and in the outcomes definition related to the assessment of the quality level of the services performed.

Particularly, the social report is divided into three parts: Identity of Institution; Management Results; Organization and Management Trends. The first section analyzes the organization and the characteristics of the territory. Furthermore, the management policies connected to the areas of the budget drawn up according to the cash accounting system are highlighted (for example the policies for the management of services and for the environment). It is noted that these policies are not articulated according to a specific category of stakeholders. The administrators of the local body highlight the importance of stakeholders [54] but neglect the analysis of the specific destination of resources and policies by categories of subjects. This section uses some information from the DUP and the PEG as regards the organizational structure of authority and the economic dimension of the social context. The second section relates to the operating results, which are linked to the data of the Financial Statements Account, prepared according to the cash accounting system. The costs of the most important services are presented even if they are not widely commented. There is a part dedicated to the presentation of the investment costs. The third section relates to management trends; in this part, the deviations from the entry forecasts and some macroeconomic indicators referring to the entry structure are presented. The determination of social indicators is fundamental to evaluate the impact of social policies on the territory. The investigated institution has only defined some indicators related to the way in which financial resources are allocated; this is also due to the fact that few social indicators are defined within the DUP and PEG that could support the social report. The managers interviewed also highlighted the need to define indicators applied to the specific context and for certain needs of the community. To stimulate attention to the measurement of social aspects, the Mayor highlighted the opportunity to provide incentive systems linked to social responsibilities and to managers who define specific social sustainability indicators.

With reference to the link between traditional accounting and the social report, it is noted that the main data and values are taken from the cash accounting system, budget and final documents, and therefore there is little use of the accrual accounting system. Moreover, there is a greater use of data related to income compared to the analysis of expenses. As previously highlighted, the body 
follows a logic of resources distribution and policies attribution by management areas and not by stakeholders. In addition, quantitative indicators are presented, and therefore the report does not highlight the analysis of the perceived quality of the services. The head of the economic-financial service highlights a difficult application of accrual accounting that often does not allow for reliable and complete information on the analytical costs of the services. Cost accounting could provide support for the correct allocation of resources by categories of policy recipients.

From this perspective, the interviewees perceive aspects that sometimes make traditional accounting system of local authorities incomplete in detecting aspects that have a social impact limiting integration between the traditional accounting system and the social report $[18,48]$. In this regard, the Head of the General Affairs, Social, School and Cultural Services says that:

"Social reporting system should be integrated with the traditional accounting system and it should follow the same institutional discussion and approval procedures, trying to activate participatory mechanisms by stakeholders in these procedures".

These aspects are attributable to a deficient application, from a technical-operational point of view, of the accrual accounting, despite the obligation foreseen by the normative provisions; the exclusive recognition attributed to cash accounting for expressing managerial activities in a complete manner, according to a simpler and less expensive accounting system compared to a structured accrual accounting system; the lack of a managerial culture that attributes value and meaning to the information drawn from the accrual accounting, in terms of relevance attributed to it in addressing the management activity in a more useful way.

\section{Contributions, Limitations and Open Questions}

In this paper, we explore the accounting information system of local authorities as a managerial tool to improve social sustainability. First of all, our case study highlights that social reporting constitutes the instrument institutionally recognized as a means of internal and external communication of the sustainable territorial development of a public body, in terms of goals, actions and results programmed and achieved. Through this, the generality of the subjects (local municipality, citizens and the other stakeholders) benefits from this information.

Secondly, our results contribute to enhancing our knowledge about the role of public accounting system in defining specific instruments and adopting managerial approaches to support sustainable territorial development policies and programs. In particular, our study underlines the importance of institutional and organizational preconditions in terms of:

- Identifying a system of values and principles that are assigned to social reporting, and therefore to social sustainability, the essential and finalistic role that qualifies and characterizes the public organization activities;

- Recognizing the strengths and weaknesses of its organizational and managerial structure, initiating a process of requalification and renewal of its structures and administrative apparatus;

- Examining the accounting information system, highlighting any substantial and procedural deficiencies that may limit the adoption of social reporting models;

- Attributing a political-institutional relevance to the social reporting process, considering the social accounting documents as tools to support the administration for making decisions and for orienting its management according to its social sustainability vision $[11,47,48]$.

Thirdly, our research contributes to identify the main characteristics of accounting instruments for social sustainability, which are briefly:

- Quality of communication: they guarantee stakeholders through an appropriate review of the accounting instruments, an adequate communication regarding the programs and results achieved according to a precise expositive and descriptive logic [63,71]; 
- Transparency: the use of transparent channels to make data and information accessible to the community [73];

- Stakeholders mapping: reporting in the accounting documents (for example, the DUP) an adequate process of identifying the stakeholders and creating the conditions for the activation of a relationships [54];

- Consistency and reliability of the social accounting systems: completeness, consistency and reliability of the preventive documents (DUP-PEG-Budget) of the accounting system to ensure the quality of social information [17];

- Integrated accounting: the use of accrual accounting data integrated with cash accounting can improve the social performance measurement [74];

- Social indicators identification and selection: the identification in the preventive (DUP-PEG) and final (performance report) accounting documents of those indicators that assume a relevance with respect to social sustainability (for example, policies for social integration; level of participation in policy and institutions; measurement of social networks; level of the territorial economic and social well-being; measurement of work and reconciliation with the quality of life) [30];

- Application context of the social indexes: the definition of accounting tools having detailed indicators for specific needs of community and for local development;

- Incentive and evaluation systems: the consideration in the accounting documents (PEG) of personnel evaluation systems linked to social responsibility performances;

- Procedures: the definition of paradigms and procedural methods for preparing and approving accounting documents that favor stakeholders' needs and participation [28].

This consideration, however, raises some doubts related to the growing need for accountability and to the adequacy of the current accounting system to meet this requirement by putting in place an effective communication and comparison system with the recipient subjects.

The structure of the accounting system is sometimes not suitable for developing a complete accountability and sustainability process in public organization; in fact, this requirement requires a different reconfiguration of the system itself in order to make it suitable for pursuing the social reporting objectives. In particular, the information and economic data, resulting from the reporting system, are not always entirely usable and understandable externally and, in this sense, they partially fulfil the task of representing results that specifically meet the information needs.

The achievement of an internal balance between resource management processes and the identification of skills and responsibilities would avoid the divergence between the purposes and methods for configuring and implementing organizational and managerial models.

In fact, we have underlined in our analysis that greater misalignment reduces the level of internal accountability. This can negatively affect the external profile of accountability, since the importance of public activity is related to its impact on local development and on the actions aimed at sustainability $[15,16]$.

\section{Conclusions}

Considering that the social dimension has an essential place in the institutional choices regarding social sustainability, the social reporting documents should be considered as a system to be integrated with the traditional accounting by entering into the programming procedures currently in place in the local authority for the accounting documents' approval. Our case study identifies the areas of complementarity between the two tools and the critical issues related to differences in reporting and data reliability. The results are useful for policy makers to define managerial tools that can better integrate the two accounting systems in support of sustainable territorial development policies and programs. Our analysis shows that social reporting is essential in promoting social sustainability and in evaluating the effects of their choices, not only within the public administration, but also externally for the local territory and its community. 
In this regard, the late production and approval of the preventive accounting documents make any planning system lacking, since the coordinated process that links programming to the management phase is not fulfilled according to a coherent and rational operating logic. These problematic aspects create a weak basis for the affirmation of social reporting models. In the analysis carried out, the investigated body underlines the essentiality of the social aspects during the strategic and operational planning, and measurement of the results achieved. Since the preventive phase identifies the objectives and fulfills the so-called social efficacy, intended as an activity aimed at satisfying public needs, the reporting phase is connected, with respect to the accountability, to the management results through a verification of the achievement of certain levels of efficiency and productivity.

Our results show that, for the purposes of social reporting, the accounting system should be able to detect and represent the management phases and the performance achieved following a logic of interdependence. This should ensure consistency between the aims of the public organization, expressed and measured through this accounting system, and the needs of the socio-economic environment. The consideration of the social elements technically implies the expansion of the information content of the accounting system in an integrated perspective in order to use the links between cash and accrual accounting. Among the future research, we suggest extending our analysis using other methodologies for the reporting activities such as the Global Reporting Initiative (GRI). This suggests specific indicators for each sustainability dimension concerning the main economic sectors and products' activities. Starting from the GRI list could be useful to identify the related costs in the public account.

In addition, we believe that the results of the analysis can be a guide for local administrators to implement social reporting systems integrated with the traditional accounting system. In addition, some local governments that prepare social reporting documents, often of a descriptive nature, or without a specific correlation with traditional accounting documents, can identify some elements to improve the integration and the social impact of the information produced.

Finally, an essential approach for the local body, in order to integrate the accounting system with the essential social information, relates to the identification of those elements aimed at evaluating and measuring the institution's ability to attract resources and the public consent necessary to operate in the socio-economic context. In this sense, a future line of research could analyze the link between these elements that emerged from the analysis and the development of social sustainability accounting systems.

The growing tendency to develop public accountability processes attributes a substantial role to the information content of the accounting system aimed at representing managerial aspects, not only from a mere allocative and authorization logic, but also according to a broader concept that re-evaluates and reconfigures the accounting and reporting system. In its integrated configuration, the social reporting is suitable to represent not only the economic and financial elements, but also to provide a disclosure of information on social sustainable impacts. The identification of the stakeholders with which the organization interacts involves, in order to identify parameters useful for monitoring and measuring the degree of their expectations, the choice and collection of accounting data that are valid for the representation of the relationships and the evaluation of the communication effectiveness between institution and social context. We are aware that a limit of our explorative research is represented by the use of a single case study, so any generalization of the results is not possible. Similarly, a limited number of interviews addressed to internal stakeholders, such as politicians and administrative staff, gives a partial vision of the studied phenomenon, compared to the information that is obtainable by extending the interviews to other types of stakeholders. Examining the external stakeholders' perceptions could be relevant to understanding the effectiveness of communication and the usefulness of social accounting tools for the community. However, these limitations and open questions discussed above may represent a starting point for future research.

Author Contributions: Conceptualization, E.C. and M.C.L.; methodology, E.C. and M.C.L.; formal analysis, M.C.L.; investigation, E.C.; resources, E.C.; data curation, E.C. and M.C.L.; writing-original draft preparation, 
E.C. and M.C.L.; writing-review and editing, E.C. and M.C.L.; supervision, E.C. and M.C.L. All authors have read and agreed to the published version of the manuscript. Though this paper is the ultimate outcome of a joint effort, it is possible to ascribe Sects. 3,4,6,8 to Eleonora Cardillo and 1,2,5,7 to Maria Cristina Longo.

Funding: This research received no external funding.

Acknowledgments: We gratefully acknowledge the editors of this special issue, the three anonymous reviewers, the administrators and public managers of the analyzed municipality for their support and the Department of Economics and Business, University of Catania.

Conflicts of Interest: The authors declare no conflict of interest.

\section{References}

1. Gray, R.; Bebbington, J. An Account of Sustainability: Failure, Success and a Reconceptualisation. Crit. Perspect. Account. 2001, 12, 557-587.

2. Henriques, A.; Richardson, J. The Triple Bottom Line: Does It All Add Up? Assessing the Sustainability of Business and CSR; Earthscan: London, UK, 2004; pp. 1-208.

3. Medeiros, E. Portugal 2020: An Effective Policy Platform to Promote Sustainable Territorial Development? Sustainability 2020, 12, 1126. [CrossRef]

4. Prezioso, M.; D’Orazio, A.; Coronato, M.; Pigliucci, M.; Sargolini, M.; Idone, M.T.; Pierantoni, I.; Omizzolo, A.; Cetara, L.; Streifeneder, T.; et al. LinkPAs—Linking Networks of Protected Areas to Territorial Development; Scientific report; ESPON: Luxembourg, 2018.

5. Longo, M.C. Social Entrepreneurship and Management Tools. In Insights and Emerging Issues on Value Sharing among Firms and Public Organizations; Giappichelli: Torino, Italy, 2018; ISBN 978-88-9211438-8.

6. European Commission. Corporate Social Responsibility, National Public Policies in the European Union, Compendium. 2014. Available online: https://ec.europa.eu/digital-single-market/en/news/corporate-socialresponsibility-national-public-policies-european-union-compendium-2014 (accessed on 24 April 2020).

7. Global Reporting Initiative. Available online: http://database.globalreporting.org/search/ (accessed on 22 April 2020).

8. Gray, R. Of Messiness, Systems and Sustainability: Towards a more Social and Environmental Finance and Accounting. Br. Account. Rev. 2002, 34, 357-386. [CrossRef]

9. Bebbington, J.; Tan, J. Accounting for sustainability. Chart. Account. J. 1996, 75, 75-76.

10. Mahadeo, J.D.; Oogarah-Hanuman, V.; Soobaroyen, T. Changes in social and environmental reporting practices in an emerging economy (2004-2007): Exploring the relevance of stakeholder and legitimacy theories. Account. Forum 2011, 35, 158-175. [CrossRef]

11. Deegan, C.; Soltys, S. Social accounting research: An Australasian perspective. Account. Forum 2007, 31, 73-89. [CrossRef]

12. Carnegie, G.D.; West, B.P. Making Accounting Accountable in the Public Sector. Crit. Perspect. Account. 2005, 16, 905-928. [CrossRef]

13. Broadbent, J.; Guthrie, J. Changes in the Public Sector: A Review of Recent "Alternative" Accounting Research. Account. Audit. Account. J. 1992, 5, 3-31. [CrossRef]

14. Guthrie, J. Application of Accrual Accounting in the Australian Public Sector - Rhetoric or Reality? Financ. Account. Manag. 1998, 14, 1-19. [CrossRef]

15. Gray, R.H. Accountability, Financial Reporting and the Not-for-Profit Sector. Br. Account. Rev. 1983, 15, 3-23.

16. Stewart, J.D. The role of information in public accountability. In Issues in Public Sector Accounting; Hopwood, A., Tomkins, C., Eds.; Phillip Allan Publishers Limited: London, UK, 1984; pp. 15-34.

17. Pallot, J. Elements of a Theoretical Framework for Public Sector Accounting. Account. Audit. Account. J. 1992, 5, 38-59. [CrossRef]

18. Gray, R.; Bebbington, J. Environmental, accounting, managerialism and sustainability: Is this planet safe in the hands of business and accounting? In Advances in Environmental Accounting \& Management; Freedman, M., Jaggi, B., Eds.; Emerald Group Publishing Limited: Bingley, UK, 2000; Volume 1, pp. 1-44.

19. European Commission, Sustainable Development. Available online: https://ec.europa.eu/environment/ sustainable-development/index_en.htm (accessed on 24 April 2020).

20. European Commission, Sustainable Development Goals. Available online: https://sustainabledevelopment. un.org/sdgs (accessed on 24 April 2020). 
21. Sachs, J.D. The Age of Sustainable Development; Columbia University Press: New York, NY, USA, 2015.

22. Medeiros, E. Spatial Planning, Territorial Development, and Territorial Impact Assessment. J. Plan. Lit. 2019, 34, 171-182. [CrossRef]

23. Dixon, T.; Green, S.; Connaughton, J. Sustainable Futures in the Built Environment to 2050: A Foresight Approach to Construction and Development; John Wiley: Hoboken, NJ, USA, 2018.

24. Georgescu, M.A.; Herman, E. Productive employment for inclusive and sustainable development in European Union countries: A multivariate analysis. Sustainability 2019, 11, 1771. [CrossRef]

25. Cotella, G. The urban dimension of EU Cohesion Policy. In Territorial Cohesion: The Urban Dimension; Medeiros, E., Ed.; Springer: Cham, Switzerland, 2019; pp. 133-151.

26. Carta, M. Reimagining urbanism. In Creative, Smart and Green Cities for the Changing Times; List Lab: Trento, Italy, 2014.

27. Shao, G.; Li, F.; Tang, L. Multidisciplinary perspectives on sustainable development. Int. J. Sustain. Dev. World Ecol. 2011, 18, 187-189. [CrossRef]

28. Zink, K.J. Stakeholder orientation and corporate social responsibility as a precondition for sustainability. Total Qual. Manag. Bus. Excell. 2005, 16, 1041-1052. [CrossRef]

29. Rafiaani, P.; Kuppens, T.; Van Deal, M.; Azadi, H.; Lebailly, P.; Van Passel, S. Social sustainability assessments in the biobased economy: Towards a systemic approach. Renew. Sustain. Energy Rev. 2018, 82, 1839-1853. [CrossRef]

30. Gray, R.; Owen, D.; Adams, C. Accounting \& Accountability: Changes and Challenges in Corporate Social and Environmental Reporting; Prentice Hall: London, UK, 1996.

31. Taylor, D.W.; Rosair, M. The Effects of Participating Parties, the Public and Size on Government Departments' Accountability Disclosures in Annual Reports. Account. Account. Perform. 2000, 6, 77-97.

32. Boyne, G.; Law, J. Accountability and Local Authority Annual Reports: The Case of Welsh District Councils. Financ. Account. Manag. 1991, 7, 179-194. [CrossRef]

33. Tower, G. A Public accountability model of accounting regulation. Br. Account. Rev. 1993, 25, 61-85. [CrossRef]

34. Khan, H.A. Globalization and the Challenges of Public Administration: Governance, Human Resources Management, Leadership, Ethics, E-Governance and Sustainability in the 21st Century; Palgrave Macmillan, Springer Nature: Cham, Switzerland, 2018; pp. 101-134.

35. Hwang, K. Bureaucratic Accountability and Performance. In Global Encyclopedia of Public Administration, Public Policy, and Governance; Farazmand, A., Ed.; Springer Nature: Cham, Switzerland, 2018.

36. Gagne, R.L. Accountability and public administration. Can. Public Adm. 1996, 39, 213-225. [CrossRef]

37. Bovens, M. Public Accountability. In The Oxford Handbook of Public Management; Ferlie, E., Lynn, L.E., Jr., Pollitt, C., Eds.; Oxford University Press: New York, NY, USA, 2007; pp. 182-208.

38. Sinclair, A. The Chameleon of Accountability: Forms and Discourses. Account. Organ. Soc. 1995, 20, $219-237$. [CrossRef]

39. Gray, A.; Jenkins, W. Codes of Accountability in the New Public Sector. Account. Audit. Account. J. 1993, 6, 52-67. [CrossRef]

40. Parker, L.; Gould, G. Changing Public Sector Accountability: Critiquing New Directions. Account. Forum 1999, 23, 109-135. [CrossRef]

41. Mussari, R. Autonomy, Responsibility, and New Public Management. In International Perspectives on the New Public Management; Jones, L.R., Schedler, K., Eds.; Jai Press: London, UK, 1997; pp. 185-201.

42. Anessi Pessina, E.; Borgonovi, E. Accounting and Accountability in Local Government: A Framework. In Comparative Issues in Local Government Accounting; Caperchione, E., Mussari, R., Eds.; Kluwer Academic Publishers: London, UK, 2000; pp. 1-9.

43. Patton, J.M. Accountability and Governmental Financial Reporting. Financ. Account. Manag. 1992, 8, $165-180$. [CrossRef]

44. Rubin, I. Budgeting for Accountability: Municipal Budgeting for the 1990s. Public Budg. Financ. 1996, 16, 112-132. [CrossRef]

45. Roberts, J.; Scapens, R. Accounting Systems and Systems of Accountability-Understanding Accounting Practices in Their Organisational Contexts. Account. Organ. Soc. 1985, 10, 443-456. [CrossRef]

46. Steccolini, I. Is the Annual Report an Accountability Medium? An Empirical Investigation into Italian Local Governments. Financ. Account. Manag. 2004, 20, 327-350. [CrossRef] 
47. Parker, L.D. Twenty-one years of social and environmental accountability research: A coming of age. Account. Forum 2011, 35, 1-10. [CrossRef]

48. Gray, R.; Dillard, J.; Spence, C. Social Accounting Research as If the World Matters. Public Manag. Rev. 2009, 11,545-573. [CrossRef]

49. Goldberg, L. The development of accounting. In Accounting Concepts Readings; Gibson, C.J., Meredith, G.G., Peterson, R., Eds.; Cassell: Melbourne, Australia, 1972; pp. 4-37.

50. Prakash, S.S. Dimensions of Corporate Social Performance: An Analytical Framework. Calif. Manag. Rev. 1975, 17, 58-64.

51. Fitch, H.G. Achieving corporate social responsibility. Acad. Manag. Rev. 1976, 1, 38-46. [CrossRef]

52. Bowman, E.H.; Haire, M. A strategic posture toward corporate social responsibility. Calif. Manag. Rev. 1975, 18, 49-58. [CrossRef]

53. Belkaoui, A.R. The impact of socio-economic accounting statements on the investment decision: An empirical study. Account. Organ. Soc. 1980, 5, 263-283. [CrossRef]

54. Shocker, A.D.; Sethi, S.P. An Approach to Incorporating Social Preferences in Developing Corporate Action Strategies. In The Unstable Ground Corporate Social Policy in a Dynamic Society; Sethi, S.P., Ed.; Melville Publishing Company: Los Angeles, CA, USA, 1974; pp. 67-80.

55. Dowling, J.; Pfeffer, J. Organizational Legitimacy: Social Values and Organizational Behavior. Pac. Sociol. Rev. 1975, 18, 122-136. [CrossRef]

56. Lindblom, C.E. The Accountability of Private Enterprise: Private No, Enterprise Yes. In Social Accounting for Corporations; Tinker, A.M., Ed.; Marcus Wiener Publishers: New York, NY, USA, 1984; pp. 13-37.

57. Ramanathan, K.V. Toward a Theory of Corporate Social Accounting. Account. Rev. 1976, 51, 516-528.

58. Burke, R.C. Decision Making in Complex Times: The Contribution of a Social Accounting Information System; Society of Management Accountants of Canada: Hamilton, ON, Canada, 1984.

59. Wartick, S.L.; Cochran, P.L. The evolution of the corporate social performance model. Acad. Manag. Rev. 1985, 10, 758-769. [CrossRef]

60. Lindblom, C.E. The Implication of Organizational Legitimacy for Corporate Social Performance and Disclosure. In Proceedings of the Critical Perspectives on Accounting Conference, New York, NY, USA, 16-18 April 1993.

61. Mathews, M.R. Socially Responsible Accounting; Chapman \& Hall: London, UK, 1993.

62. Gray, R.; Owen, D.; Maunders, K. Researching the information content of social responsibility disclosure: A comment. Br. Account. Rev. 1987, 19, 169-176.

63. Marcuccio, M.; Steccolini, I. Patterns of Voluntary Extended Performance Reporting in Italian Local Authorities. Int. J. Public Sect. Manag. 2009, 22, 146-167. [CrossRef]

64. Belkaoui, A.R. Accounting Theory, 3rd ed.; Academic Press: London, UK, 1992.

65. Belkaoui, A.R. Accounting Theory, 5th ed.; Cengage Learning EMEA: Andover, UK, 2004.

66. Lee, M.D.P. A review of the theories of corporate social responsibility: Its evolutionary path and the road ahead. Int. J. Manag. Rev. 2008, 10, 53-73. [CrossRef]

67. Rahman, N.; Post, C. Measurement Issues in Environmental Corporate Social Responsibility (ECSR): Toward a Transparent, Reliable, and Construct Valid Instrument. J. Bus. Ethics 2012, 105, 307-319. [CrossRef]

68. Paunescu, C.F. Social Accounting-Source of Relevant Information in Assessing the Social Responsability of the Organization. Oradea J. Bus. Econ. 2019, 4, 52-59.

69. Man, M.; Ciurea, M. Transparency of Accounting Information in Achieving Good Corporate Governance. True View and Fair Value. Soc. Sci. Educ. Res. Rev. 2016, 3, 41-62.

70. Ihlen, Ø.; Bartlett, J.L.; May, S. Corporate Social Responsibility and Communication. In The Handbook of Communication and Corporate Social Responsibility, 1st ed.; Ihlen, Ø., Bartlett, J.L., May, S., Eds.; Wiley-Blackwell: Chichester, UK, 2011; pp. 3-22.

71. Crane, A.; Glozer, S. Researching Corporate Social Responsibility Communication: Themes, Opportunities and Challenges. J. Manag. Stud. 2016, 53, 1223-1252. [CrossRef]

72. Farneti, F.; Siboni, B. An Analysis of the Italian Governmental Guidelines and of the Local Governments' Practices for Social Reports. Sustain. Account. Manag. Policy J. 2011, 2, 101-125. [CrossRef] 
73. Longo, M.C.; Cardillo, E. Transparency in Open Administrations: Communication, Accountability and Community's Quality of Life. Evidences from Innovative Practices in Italian Local Governments. In Entrepreneurial and Innovative Practices in Public Institutions. A Quality of Life Approach; Leitão, J., Alves, H., Eds.; Springer International Publishing: Cham, Switzerland, 2016; pp. 99-122.

74. Aiken, M.; Capitanio, C. Accrual accounting valuations and accountability in government: A potentially pernicious union. Aust. J. Public Adm. 1995, 54, 564-576. [CrossRef]

75. Bruns, H.-J. Accounting change and value creation in public services-Do relational archetypes make a difference in improving public service performance? Crit. Perspect. Account. 2014, 25, 339-367. [CrossRef]

76. Anessi-Pessina, E.; Nasi, G.; Steccolini, I. Accounting innovations: A contingent view on italian local governments. J. Public Budg. Account. Financ. Manag. 2010, 22, 250-271. [CrossRef]

77. Montesinos, V.; Pina, V.; Vela, J.M. Comparative Analysis of Governmental Accounting Systems in OECD Countries: An Empirical Approach. In International Research in Public Sector Accounting, Reporting and Auditing; Montesinos, V., Vela, J.M., Eds.; Instituto Valenciano de Investigaciones: Valencia, Spain, 1995; pp. 161-184.

78. Nasi, G.; Steccolini, I. Implementation of accounting reforms. Public Manag. Rev. 2008, 10, 175-196. [CrossRef]

79. Guthrie, J.; Johnson, M. Commercialisation of the Public Sector: Why, How and for What? A Prospective View. In Governance and Economic Efficiency; Whiltshire, K., Ed.; CEDA: Sydney, Australia, 1994; pp. 87-108.

80. Yin, R.K. Applications of Case Study Research, 3rd ed.; Sage Publications: Thousand Oaks, CA, USA, 2011.

81. Eisenhardt, K.M. Building Theories from Case Study Research. Acad. Manag. Rev. 1989, 14, 532-550. [CrossRef]

82. Eisenhardt, K.M.; Graebner, M.E. Theory Building from Cases: Opportunities and Challenges. Acad. Manag. J. 2007, 50, 25-32. [CrossRef]

83. Noor, K.B.M. Case Study: A Strategic Research Methodology. Am. J. Appl. Sci. 2008, 5, 1602-1604. [CrossRef]

84. Yin, R.K. Case Study Research: Design and Methods, 3rd ed.; Sage Publications: Thousand Oaks, CA, USA, 2003.

(C) 2020 by the authors. Licensee MDPI, Basel, Switzerland. This article is an open access article distributed under the terms and conditions of the Creative Commons Attribution (CC BY) license (http://creativecommons.org/licenses/by/4.0/). 